\title{
Controlling Immigration Manually: Lessons from Moscow (Russia)
}

\author{
Caress Schenk \\ School of Humanities and Social Sciences, Nazarbaev University, Astana, Kazakhstan
}

This is an Accepted Manuscript of an article published by Taylor \& Francis in Europe-Asia Studies in 2013, available online: http://www.tandfonline.com/doi/abs/10.1080/09668136.2013.824242

Abstract: In 2007, the Russian government instituted quotas for immigrant work permits that have consistently been lower than actual labour demand. While low quotas are politically popular on the mass level, this article argues that low quotas are also a tool of the government to distribute patronage resources to regional political and economic elites. Decisions about quotas are firmly in the hands of prime minister Putin, giving him a powerful tool to control the immigration process and labour market manually. While this manual control is effective in the short-term to manage contentious policy arenas, it suffers a number of long term consequences.

Passing through immigration at Sheremetyevo airport, passport and registration documents in hand, evokes certain feelings of dread for even the well-seasoned traveller to Russia. Visiting Russia can be daunting in terms of logistics and it has become only more so in recent years as visas and invitations are harder to come by. The process has become more complex even for citizens of former Soviet countries who enjoy visa-free travel to Russia. New immigration legislation, enacted in 2007, had many experts heralding a new period of liberalization, especially for labourers from the countries of the Commonwealth of Independent States (Sodruzhestvo Nezavisimykh Gosudarstv, CIS). These migrant workers for the first time were able to apply for work permits themselves and move freely between employers. Yet in a "two steps forward, three steps back," dance toward increasing authoritarianism in Russia the legislation erected new barriers that prevent migrants from legalizing. The most important of these barriers is a quota system limiting the number of work permits issued each year to CIS migrants.

The quota mechanism introduced in 2007 has become the focal point of increasing restriction since 2008 and I argue in this paper that it represents a tool for the Russian government to manually control immigration processes. 'Manual control' refers to the direct intervention of top political elites in policy making. It is a deliberate strategy adopted by Putin ahead of the 2008 presidential elections (Zherebenkov 2007). Since then its increasing use has been noted by various observers of Russian politics (Petrov, Lipman \& Hale 2010; Arkhipov \& Pronina 2010). Therefore, the argument advanced here falls in line with these recent developments and enriches our understanding of the evolution of Russia's political regime by exploring the tools Russian leaders rely upon, the short term gains these tactics produce and potential problems that lie ahead. The case of immigrant quotas is particularly interesting because it allows us to trace the flow of power in the Russian political system from the office of president to prime minister since 
2008 by observing that the instrument of manual control has been exercised primarily by Vladimir Putin despite the end of his presidency.

Russia is the second largest country of immigration in the world and like all immigrant-receiving countries must find strategies to manage new populations alongside the native population. In the Russian case, manual control of the quota system has become the preferred strategy because immigrants are at the centre of tremendous tension between labour needs and xenophobic tendencies in society. Russia is in the midst of a demographic crisis that is particularly acute in the working age population, making immigrants an important source of labour growth (Dmitriyev 2007; Andrienko \& Guriev 2005; Korobkov \& Zaionchkovskaia 2004). Yet substantial portions of the Russian population do not welcome migrant laborers despite their utility, focusing rather on xenophobic sentiments (Schenk 2010; Alexseev 2010). The tension between labour needs and social unrest is of great concern to Russia's regime because its legitimacy hinges on providing both economic and social stability, and so political elites must intervene directly to achieve balance.

The government manages the dual demands of society and economy by creating strict quotas that make it difficult for migrants to work legally, thereby forcing them into the informal sector where they become a cheap source of labour. Strict quotas that do not meet labour demand are a populist response to xenophobia, creating the perception that the government is clamping down on immigration. Setting quotas in this manner increases the cost of participating in the formal economy and together with corruption pushes more and more foreign workers into the informal sector. Informal migrants fill gaps in the labour market and are an attractive alternative for employers who prefer to cut costs. Because quotas are allocated by region, regional elites are essential for ensuring the balance between society and economy is maintained and thereby translating regime legitimacy to the local level. For this reason regional elites are key players in a patronage network that links top Kremlin officials to political and economic elites in Russia's regions. I hypothesize that the Kremlin uses manual control of the quota system to manage these patronage networks, ensuring the loyalty and compliance of regional political and economic actors by providing low quotas. Regional elites in turn use low quotas to appeal to xenophobic elements in society while at the same time providing informal labour for employers. In this analysis, I focus on the economic side of this equation, and particularly on economic elites who occupy positions in key migrant-employing sectors of the economy as beneficiaries of low quotas.

The evidence for this article focuses on the Moscow case and draws from direct observations, expert interviews, government documents and media accounts. ${ }^{1}$ In order to pursue the hypothesis that the prime minister is using immigrant quotas to manage the loyalty of interested actors, I will first develop a general theoretical framework for manual control, showing how it developed as an instrument of Putin's personal power and elaborating on its purpose and various usages. I will then show how the quota system furthers the power of manual control by codifying an ongoing demand for the prime minister's involvement. In this section I will explore both the justification for and labour market effects of low quotas. Finally, I will show how manual control of immigration distributed highly desirable resources to political and economic elites in the

\footnotetext{
${ }^{1}$ Field research was conducted during 2009 using a grant from the American Councils for International Education.
} 
Moscow case during the tenure of Mayor Yurii Luzhkov. Moscow is a particularly appropriate focus for this type of study because it is the primary destination for immigrants and as such it represents an intensified picture of immigration relations in Russia. Because of Moscow's special status as a separate subject of the Russian Federation it also represents the complex nature of patronage ties between federal and regional elites and shows how manual control can be an effective, albeit short term, strategy to manage disparate interests.

\section{Manual Control}

Manual control can be seen in a number of policy areas including the electoral system Petrov, Lipman \& Hale 2010 (Petrov, Lipman and Hale 2010), federal reforms (Konitzer \& Wegren 2006; Hahn 2001) and the media (Becker 2004; Panfilov 2000). That these arenas have come under increasing authoritarian control since the beginning of the Putin presidency is welldocumented in the literature (Ross 2005; Lipman 2005; Remington 2006). The idea that Russia's ruling elite rely on manual control, or personal intervention in the policy process, has recently been cited as strategy to maintain political power at critical moments of public backlash (Petrov, Lipman \& Hale 2010). The present article builds on this logic to define manual control as a technique of authoritarian rule employed by Russian political elites that uses personal intervention in policy making in order to maintain popular legitimacy for the regime and shore up the vertical of power.

Manual control is employed preventatively in some cases in order to centralize control under the Kremlin's authority, and in other cases is a reaction to either exogenous shocks (i.e. natural disasters, terrorist attacks, financial crises) or conflicts between the public and elites. Because a focus on popular legitimacy through appeals to the masses does not always coincide with the management of elites in the vertical of power, manual control is necessary in cases where the balance between mass and elite interests reaches a tipping point that requires decisive action. A tipping point occurs when elites fail to uphold the Kremlin's carefully sanitized public image, causing the vertical of power to appear as if it does not have clear and authoritative boundaries. Specifically, the Kremlin has worked to ensure its image as the provider of stability and prosperity. It is able to project this image through the state-controlled media, but must step in to defend its reputation at certain points when shocks or conflicts cannot be contained.

Putin initially gained popularity and legitimacy by creating an image of a heroic yet accessible leader that borders on personality cult (White and McAllister 2003, 388). Legitimacy gained through charisma is amply theorized by Max Weber as an authoritarian principle that is nevertheless subject to failure if a leader does not provide benefits to his followers (Weber 1978, $242,266)$. Therefore the legitimacy of a charismatic leader relies on sensitivity to public opinion.

In order to prevent potential legitimacy crises, manual control becomes an essential tool to manage public opinion. A recent example occurred following wildfires throughout Russia in summer 2010. When a number of homes were destroyed near Moscow, Putin met with the victims and promised to personally oversee the reconstruction of their homes. He went so far as to have video cameras installed on the worksites that transmitted live feeds to monitors in his home and office (Arkhipov \& Pronina 2010). In this case manual control addressed the combination of the exogenous shocks of the wildfires along with a restive public who was 
beginning to blame the government for the results of the wildfires. ${ }^{2}$ It was only after visible appearances by Putin, such as one where he accompanied an airborne fire-fighting mission, that public approval ratings recovered. ${ }^{3}$ During this episode the strategy of using low-level elites as scapegoats for failures of the central government emerged and acts as a case in which the Kremlin created a tipping point between regional elites and the public by highlighting their incompetence and dismissing a number of officials (Arkhipov \& Pronina 2010).

In addition to preventing failures of legitimacy, manual control is used to shore up Putin's vertical of power either through preventative measures meant to centralize authority or reactive measures to reign in elites with designs on personal aggrandizement. Typically, discussions of the vertical of power are centred on changes made to the federal system (Ross 2005; Konitzer \& Wegren 2006; Pomeranz 2009; Hahn 2001). But the vertical of power is much less about creating a uniform legal space than it is about ensuring loyalty to the regime at all levels, from the party system (Reuter \& Remington 2009) to regional executives (Slider 2008) to the media (Becker 2004) to the public (Petrov, Lipman \& Hale 2010). The vertical of power is a broad routinisation of charisma in the sense that it institutionalizes the ongoing discretion of central political elites by carving out policy areas that require top administrative involvement. As such, it both justifies and demands manual control over institutions such as the judiciary, the federal system and the bureaucracy, subverting the rule of law and constitutional divisions of power. Manual control makes use of both formal and informal institutions to distribute patronage resources to elites at the same time that it provides policies that ensure continued regime legitimacy.

For example, Putin's decisions to create seven administrative districts with envoys directly accountable to the president and rescinded direct elections of governors demonstrate institutionalizations of manual control. The creation of seven federal districts by presidential decree placed a layer of administration between the Kremlin and regional governments with the intention of better asserting central authority in the regions (Haspel, Remington \& Smith 2006; Sakwa 2010; Pomeranz 2009; Hyde 2001).. This is an example of preventative manual control, as it was used to centralize authority and decision-making in the absence of a tipping point or exogenous shock. Central control was further solidified when legislation was passed in 2004 that carved out legal space for the president to appoint regional executives (Ross 2005; Wilson 2006). The reform was justified on the basis of an exogenous shock (the terrorist attack at Beslan), though it can also be seen as a preventative strategy in the sense that it creates ongoing Kremlin discretion over regional affairs. Not only did this move insulate the regime from potential electoral defeat (Reuter \& Remington 2009), but it ensured that only those loyal to Putin would be awarded political appointments (Slider 2008; Ross 2005). Sakwa (2010, p. 194) calls both of these reforms "para-constitutional" because they create space for the regime to function outside

\footnotetext{
${ }^{2}$ RIA Novosti, 10 August 2010, available at: http://en.rian.ru/russia/20100810/160145818.html, accessed 4 September 2010 .

${ }^{3}$ Vedomosti, 3 September 2010, available at:

http://www.vedomosti.ru/newspaper/article/244948/pozhara_kak_ne byvalo, accessed 4 September 2010.
} 
the constitution without explicitly violating it. More specifically, the reforms created institutionalized roles for the president to manually control the political landscape through granting and rescinding appointments.

This article provides evidence that manual control has followed Putin to the office of prime minister and that the legitimacy of the regime rests on him and his patronage networks. Preventative forms of manual control ensure the emasculation of all but the very top elites as they remove the ability of the judiciary, legislature and bureaucracy to function as the constitution stipulates. Responses to exogenous shocks and tipping points between public and elites elicit responses from the Kremlin which directly influence or completely bypass functions of the political machinery and issue directives based on the most pressing needs of the regime.

When all is going according to the regime's desires, corruption flourishes as patronage benefits are distributed to political and economic actors. Corruption is allowed to continue until it reaches a tipping point where it threatens the regime's reputation of providing stability and prosperity. Once the balance is tipped, top government elites can respond immediately because they are able to bypass typical channels of accountability. This use of manual control in particular creates a great deal of uncertainty among political professionals as it is not used on a daily basis and it is difficult to predict when Putin and his inner circle will deem a particular issue worthy of personal attention. It is typically only in retrospect that the presence of a tipping point can be identified, after a political or economic elite falls from grace. Uncertainty creates a situation in which the only constant is the necessity of continually proving loyalty to the top. Access to important resources and political positions are available only through such loyalty.

Putin sits at the top of this "vertical of patronage", his status reaching almost supernatural proportions. He is omnipresent, leaving his official duties to make appearances in the midst of local labour disputes and even to fight the occasional fire. His power approaches omnipotence as he shapes what truths the public will be presented via state television, covering up any corruption not addressed directly by manual control (Orttung 2006). His justice is swift and supreme as he exercises manual control to defend the common people, reward elites who are loyal and punish those who are not. Manual control, then, is fundamentally opposed to the rule of law, which would necessitate clear and predictable procedures that prevent elites at all levels from exercising power arbitrarily.

What is particularly innovative about the example of immigrant quotas is that it marks a shift in manual control as an instrument of presidential power to an instrument at the disposal of Putin in the office of prime minister. During Putin's presidency, manual control was exercised through presidential decree ( $u \mathrm{kaz}$ ) (as in the creation of seven federal districts), through firm control of the Duma (enabling legislation to rescind gubernatorial elections) (Ross 2005), or through informal institutions such as "telephone justice" where judicial independence is subverted for political purposes (Ledeneva 2008; Hendley 2009; Goldman 2005; Sakwa 2010). That quotas are issued by government decree (postanovlenie) and that this power is explicitly defined in the 2007 legislation institutionalizes the opportunity for Putin to exercise manual control, transforming the previously emasculated office of prime minister into one that is central to the functions of the political system. If Russia were a system where the rule of law was robust, this innovation would not be especially interesting because the use of governmental decree would 
merely signal approval of a quota that had been formulated according to well-defined bureaucratic procedure. As I will argue, however, this is not the case in Russia. Rather it is an example of how power can be transferred while maintaining the guise of constitutionality that has been integral to the Putin regime. The combination of an absence of rule of law and the transfer of institutional power from president to prime minister provides evidence that Putin's role in providing legitimacy to the regime through his charismatic appeal to the public and his position atop the vertical of power have remained an essential component of the stability of the political machinery.

\section{Manual Control: The Quota System}

A number of countries employ quotas to control the labour market including Austria, Italy, Spain and the United States. A quota system does not automatically imply manual control, despite the fact that it is inherently restrictive and inflexible because it places an annual upper limit on the number of migrants allowed to enter the labour force and typically cannot be amended mid-year. Nevertheless, quotas are not necessarily a bad mechanism so long as they are formulated in accordance with labour market needs and are not manipulated by officials in order to disproportionately benefit certain actors. When a quota system is implemented in a country that does not operate by the rule of law with a government that respects bureaucratic insulation, the opportunity for manual control enters. In this section, I will show how the Russian quota system belies manual control and how this manipulation produces increased numbers of illegal migrants that can be used as a patronage resource for political and economic elites at the municipal level.

The immigrant quota system is an example of Putin's personal hand in a contentious political situation. The formulation process belies a patrimonial bureaucracy that works according to political calculations and loyalties rather than according to procedure. A functioning bureaucracy relies on a meritocratic system, clear and stable hierarchy and permanent agencies with fixed jurisdictions that operate according to rules rather than the personal discretion of rulers or bureaucrats themselves (Weber 1978, pp. 956-957, 1006). Manual control interrupts the ability of bureaucrats from the ministry level down to the civil service level to operate insulated from political loyalties. The result is a system of patrimonial bureaucracy that relies on personalities rather than expertise (Taylor 2007). The example of the quota system that regulates migrant work permits is precisely this type of manual control and is an important tactic of governance in Putin's Russia.

Quotas define how many foreign workers will receive work permits in a given year. According to procedure, they are calculated yearly based on requests from employers, which are then adjusted based on various considerations by the Ministry of Health and Social Development (Minzdrav) before they proceed to the government for approval. Each year, quotas are formalized by government decree after considering input from a number of different government bureaus including the Federal Migration Service (Federal'naya Migratsionnaya Sluzhba,FMS), Ministry of Economic Development (Minekonomrazvitiya) and Federal Labour Service (Rostrud). At each stage in the process there is ample room for political and administrative discretion (Mikhaelova \& Tyuryukanova 2009). Final authority is exercised by Putin himself giving him the opportunity to exercise manual control each year as quotas are defined. 
If the quota formulation proceeded according to well-defined rules, the prime minister's decision would be merely a rubber-stamp approval of the estimates of experts. However, it is clear that other factors enter into the final decision. Low quotas are politically popular given the public disapproval of any large influx of foreign labour. When quotas were increased to 4 million for 2009 the public backlash was immediate, demanding an answer for why the government would increase quotas in a time of financial crisis. ${ }^{4}$ For example, during "A Conversation with Vladimir Putin," a question and answer session in December 2008 broadcast on television and radio, a woman asked Putin why migrant quotas were so high given unemployment rates in the financial crisis. He sympathized with her query, indicating that he believed a quota reduction was justified. Within the month, a decree was passed cutting the quota in half, essentially disregarding the entire bureaucratic procedure supposedly used to formulate the quota in the first place. Putin's decision to decrease the quota is therefore widely dubbed as populist rather than a response to true labour market needs. ${ }^{5}$

There are two potential explanations for this situation. It is certainly possible that Putin was responding to public backlash and a potential legitimacy crisis, reaffirming his position at the top of the vertical of power by bypassing bureaucratic procedure. An alternative explanation is that a lower quota had already been decided upon and the press conference was orchestrated to make Putin look sympathetic and heroic by responding to the needs of the people. Both possibilities display manual control as each recognizes the importance of public opinion as a component of popular legitimacy and solidifies Putin's role as sympathetic yet powerfully and decisively in control of the vertical of power. It also addresses a tipping point between officials in the bureaucracy, specifically in the FMS who lobby for high quotas as a way to legalize foreign workers, and the portions of the public who are concerned with losing job opportunities to foreign workers. In this way it is clear that Putin's ability to use manual control at the elite level by readjusting the original quota creates opportunity for its use at the mass level as well. Because the intervention here is immediate as it is not slowed by bureaucratic procedure, it can be used to quickly respond to potential legitimacy crises.

Low quotas are not only popular on the mass level, but they provide important patronage resources for economic and political elites as they force workers into the informal labour market. As a general principle, informal labour provides advantages to employer and worker alike. Employers are able to reduce costs by paying lower wages and avoiding taxes and social insurance payments, while workers are able to avoid paying income tax (Jahn \& Straubhaar 1999).. Barriers such as low quotas and the expectation that obtaining legal work permits will involve paying bribes to corrupt officials cause many migrants and employers to opt out of the system in order to cut costs and avoid bureaucratic headaches. Decreasing the number of migrants permitted to obtain work permits is economically advantageous in the sense that it restricts the legal space within which migrants can work, forcing the remainder into the shadow sphere. The use of a quota system itself does not imply that informal labour will increase. Rather

\footnotetext{
${ }^{4}$ Russkii Obozrevatel, 4 December 2009, available at: http://www.rus-obr.ru/days/1331, accessed 6 July 2009.

${ }^{5}$ Novaya Politika, 14 October 2009, available at: http://www.novopol.ru/text77308.html, accessed 22 December 2009.
} 
increasing informality is a result of quotas not aligning with labour market need as I will now demonstrate.

When CIS workers were first included in the quota numbers in 2007, six million work permits were allotted (see table one). ${ }^{6}$ The FMS suggested this generous quota as a sort of amnesty program to legalize migrants already on the territory of the Russian Federation and an estimated four million illegal migrants were regularized as a result. ${ }^{7}$ The amnesty allowance is consistent with estimates of a stable population of six million migrants (legal and illegal) in Russia at any given time (Gritsyuk 2010; Tyuryukanova 2009a; Ioffe \& Zayonchkovskaya 2010). ${ }^{8}$ It is logical, then, that a quota set lower than six million would force migrants back into the shadow labour market. ${ }^{9}$ Furthermore, considering the number of illegal migrant workers in Russia is estimated to be 5-10 million, which is a telling indicator of true labour market demand, any quota of less than five million will almost certainly ensure there will be a drastically insufficient number of work permits for migrant workers on the Russian Federation territory (Kroschenko \& Zibarev 2009).

[table one about here]

Since 2007 quotas have been consistently lower than the actual need for foreign labour and have decreased dramatically each year. In 2008 the quota was set for 1.8 million but in a number of regions including Moscow it was exhausted by May, evidence that the quotas allotted insufficient permits to meet labour market demand (FMS 2008a). The FMS announced in August 2008 that it would allocate additional quotas, though it was not until October that Putin officially

\footnotetext{
${ }^{6}$ Prior to 2007 migrants from non-CIS countries were subject to a quota, whereas CIS citizens had no such restriction. Since 2007 the quotas are not disaggregated for CIS and non-CIS citizens.

${ }^{7}$ Interview with Zhanna Zayonchkovskaya, 'Kvoty s potolka' in Ogoniok 20 August 2007; Interview with Vyacheslav Postavnin, president of Migration in the $21^{\text {st }}$ Century, available at:
} http://rian.ru/interview/20090701/176027755.html, accessed 13 December 2009.

${ }^{8}$ Estimates of the total number of migrants in Russia (including legal and illegal) have not changed in recent years. In 2007-2008, there were an estimated 6-7 million migrants and in 2010 5-6 million (Gritsyuk 2010; Tyuryukanova 2009; Ioffe \& Zayonchkovskaya 2010). Furthermore the flow of migrants has not changed. Around 20 million foreign citizens enter Russia every year and this number has remained stable for the last several years (Egorova 2009, 52).

${ }^{9}$ According to Article 5.5 of Federal Law 115, a CIS migrant's registration may be extended beyond 90 days only if they have a work contract, yet the registration cannot be of a duration longer than one year from the initial date of entry. After the expiry of registration, the law stipulates the foreigner must leave the country (Article 5.2). 
increased the quota to 3.4 million (FMS 2008b). ${ }^{10}$ The quota for 2009 was set at four million based on requests by employers, but was later reduced by Putin to two million. He cited a need to protect the labour market for Russian citizens in a time of economic crisis as he used manual control to bypass bureaucratic procedure (Gritsyuk 2008). ${ }^{11}$ The quota for 2010 was initially kept at two million despite continued lobbying by a number of regions for further reductions. ${ }^{12}$ It was eventually reduced to 1.3 million in the final days of 2009 after Putin met with Mikhail Shmakov, the leader of the Federation of Independent Trade Unions (Federatsiya Nezavisimykh Profosoyuzov Rossii) who lobbied for lower quotas in order to protect the native labour force (Bratersky 2010). ${ }^{13}$

Given that the migrant population is stable at six million, decreased quotas inevitably cause an increase in illegality. Experts estimate that the number of migrants has remained at a constant 11.5 million in Moscow. Yet the quota for Moscow has decreased from 750,000 in 2007 to 200,000 in 2010, ensuring that the majority of migrants (between $80-87 \%$ ) will remain in the shadows (see table 1). Former Moscow mayor Yurii Luzhkov has corroborated these figures, estimating that there are around 800,000 migrants in Moscow working outside the quota system. ${ }^{14}$ According to the data in table one, the proportion of migrant workers who are illegal is rising quickly in Russia and even more quickly in Moscow. If the projection for 2011 holds true, Moscow will have a record rate of illegal workers, at least $8 \%$ higher than in 2005 and $19 \%$ higher than in 2006 before quotas were instituted. The data in table 1 clearly shows that as the quota decreases, the number of illegal migrants increases. As quotas continue to tighten, we can expect to see a greater share of migration being forced into the informal sector.

Low quotas show how manual control functions at the mass and elite levels, providing popular legitimacy while reinforcing the idea that Putin himself is in charge and can act quickly and decisively without administrative constraints. Further, by continually lowering quotas, the government is providing an increasing pool of informal workers that can then be used to manage patronage networks. A number of actors benefit from informality in the Russian immigration system including regional political elites who sit atop patronage networks of local oligarchs, the

10 Government Decision \#737, 3 October 2008.

${ }^{11}$ Government Decision \#834, 7 November 2008.

${ }^{12}$ For example, in Volgograd, Krasnoyarsk and Tatarstan. Komsomol'skaya Pravda, 7 December 2009, available at: http://volgograd.kp.ru/online/news/582818/, accessed 22 December 2009; Newslab, 21 December 2009, available at: http://www.newslab.ru/news/298249, accessed 22 December 2009; Regions.ru, 18 December 2009, available at: http://www.regions.ru/news/2259883/, accessed 22 December 2009.

13 RIA Novosti, 1 January 2010, available at: http://www.rian.ru/economy/20100101/202498551.html, accessed 31 December 2009.

14 Interfax, 18 February 2010, available at: http://www.gazeta.ru/news/lenta/2010/02/18/n_1459292.shtml, accessed 22 March 2010. 
local oligarchs themselves along with other economic entrepreneurs who employ migrants, civil servants (both bureaucrats and police) who collect bribes from migrants and employers, middlemen who charge exorbitant prices to provide migrants work, and migrants who despite poor working conditions are often better off than they were in their country of origin. This situation allows corruption to thrive as patronage benefits are informally distributed to political and economic actors. Corruption proceeds unhindered until a tipping point is reached, where the regime's ability to protect the public from power-hungry or incompetent regional elites as a matter of popular legitimacy can no longer be balanced with keeping patronage networks intact. Once this tipping point occurs, top government elites can respond immediately, as Putin did by cutting quotas after the call-in program, because they are not slowed by the accountability of bureaucratic procedure. However, because most actors are uncertain when a tipping point will be reached, they must maintain vigilant loyalty or risk being the victim of manual control. This manual control of the system is exercised at the highest levels, emanating from the prime minister's office to balance mass and elite interests. The remainder of this discussion will focus on how patronage was managed between the prime minister and regional political elites and oligarchs in Moscow during Luzhkov's tenure, demonstrating why manual control is necessary to balance disparate demands.

\section{Managing the Patronage Network}

As discussed earlier, manual control of the federal system has involved rescinding the election of executives in order to ensure the regime would be insulated from potential electoral defeat (Reuter \& Remington 2009) and that only those loyal to Putin would be awarded governorships (Slider 2008; Ross 2005). By looking at the case of Moscow, this discussion of bringing federal units in line with the centre through the vertical of power is foundational. It is not illogical to argue that the federal government would have the greatest opportunity to affect changes and assert its agenda in Moscow as the Kremlin is a five minute walk from the mayor's office giving the federal level ample opportunity for oversight and monitoring. But Moscow is a complex mix of Kremlin and municipal power and the nature of patronage is not as clear as issuing and implementing federal policies. This case is not only a matter of manual control of the federal system, it is an example of how manual control is an essential tool in the management of patronage networks. As such it provides evidence for the hypothesis that political elites use manual control of the quota system to ensure the loyalty and compliance of political and economic actors by providing the benefit of an ample supply of cheap informal labour. It also shows how manual control begets further uses of manual control because it creates the potential for elite conflict.

The evidence for this argument will suggest looks at entrenched patronages network between the federal and municipal levels and between the municipal government and local oligarchs during the tenure of mayor Yurii Luzhkov. Municipal political elites act as an important conduit, lobbying for low quotas in order to ensure their clients will benefit from informal labour, while providing loyalty to the federal regime in order to maintain their political position. Regional political elites must balance public legitimacy alongside the distribution of benefits to regional elites in much the same way federal elites work to keep conflicting interests from reaching a tipping point. Local economic elites, for their part, provide loyalty and monetary benefits to the city government. In addition, the city government itself uses informal immigrant labour and therefore benefit directly from low quotas. The presence of these patronage relationships makes 
manual control of immigrant quotas an effective tool of governance in the short-term though the regime must always be aware of potential tipping points that could lead to legitimacy crises.

Luzhkov long sat at the top of a municipal patronage network that made him a pivotal figure between federal political elites and local oligarchs. Luzhkov had both mass and elite appeal that contributed to his popular legitimacy and ability to provide patronage resources for economic elites. He accomplished these tasks by using his loyalty to the federal regime to negotiate benefits for those in his sphere of interest. The Moscow city government has been a force that wields disproportionate leverage in Russian politics. Muscovites deem it more like a state than a city, and say that the federal government is beholden to it because when things are going well in Moscow, things are going well in Russia. During his long tenure, Luzhkov was considered an international figure who assumed a diplomatic role to advocate for Moscow's interests (Medvedev 2004)

Luzhkov's picture is proudly displayed in the museums and walls of his projects such as the reconstruction of Catherine the Great's Palace just south of Moscow. Projects like this and the reconstruction of the Cathedral of Christ the Saviour have been called "morale-boosting showcase projects," that focus more on leaving a legacy than developing the city (Colton 1999). Nevertheless, Luzhkov proved to be a popular mayor, retaining his post from 1992-2010, and received a high percentage of votes in elections (89.6\% in 1996 and $71.5 \%$ in 1999) before his position, along with all regional executives, became subject to appointment after 2004 (Medvedev 2004). He was a powerful stabilizing force, ushering in enormous growth and development despite the instability of the 1990s.

It is this stability, as well as Luzhkov's ability to deliver votes for the Kremlin's candidates in national elections (Whitmore 2010), that helped produce legitimacy for the federal regime and thus was key to the patronage relationship between the government and the city during the Luzhkov period. Many details of the relationship between federal and municipal government are mere speculation as the nature of patronage is secretive. What is clear is that as long as Luzhkov provided the federal regime with continued legitimacy, his position was secure and he received patronage resources, in the case of the present argument the informal labour provided through low immigrant quotas.

Luzhkov was a vociferous critic of the 2007 migration legislation that allowed migrants to apply for work permits themselves and move freely between employers, claiming it was too liberal and proposing instead that a new police force especially dedicated to immigration control should be created (Luzhkov 2006). For the duration of his tenure he continued to speak out against the legislation, consistently demanding lower and lower quotas for Moscow. ${ }^{15}$ In 2010, he came out

\footnotetext{
${ }^{15}$ Vedomosti, 18 December 2009, available at: http://demoscope.ru/weekly/2009/0403/gazeta04.php, accessed 13
}

March 2010. 
in favour of creating legislation that would shorten the period visa-free CIS citizens are allowed to stay from 90 days to 15 days. ${ }^{16}$

Luzhkov consistently couched his arguments in language of protecting the labour market for native workers and cutting down on crime. This type of rhetoric resonated with xenophobic segments of society and thus served an important function in gaining popular support and legitimacy. Nevertheless, this article argues that such rhetoric is a thinly veiled demand for greater numbers of informal workers. Luzhkov's patronage network included a number of oligarchs with controlling interests in the construction and retail (outdoor market) industries, which are the largest employers of migrants. Furthermore, the city directly employs a large number of migrants, many of whom have at least some degree of irregularity in their status. It is not surprising then that Luzhkov continually spoke out for lower quotas in order to obtain ample informal labour for the city and regional oligarchs.

\section{Municipal workers}

The city of Moscow directly employs a number of migrants, the largest sector of which is involved in municipal services such as street cleaning. The situation is curious in the migration law in 2007 stipulated migrants have no right to work in municipal services. ${ }^{17}$ Yet there is a visible presence of Central Asians in this sector. During the Soviet period these jobs were filled by Tatars, who at that time were seen as outsiders in much the same way as Central Asians are now. Nevertheless, opinions vary about whether these migrants are legal or not. One Muscovite I spoke with said they were of course legal because they wear uniforms!

An expert I spoke with estimated as many as ten migrants are paid with shadow wages for every legally documented worker. Yet it must be borne in mind that even migrants who hold work permits do not always work legally, as many employers do not register with the tax services when hiring foreign workers. ${ }^{18}$ In 2007, the FMS reported that a majority (53\%) of legal workers worked in shadow jobs. Yet in 2007, of the six million work permits allotted by quota only 1.7 million were distributed to migrants (see table 1). This means of the estimated six million migrants in Russia that year, less than one-third chose to complete the procedures to work legally. A 2008 survey showed an even larger percentage of illegal immigrants (85\%) working in shadow jobs (Tyuryukanova 2009). Furthermore, experts estimate that around $50 \%$ of migrants in 2008 were counted multiple times in the calculations of foreign labour force. Of the 6 million migrants in Russia (static), if $50 \%$ of the 1.5 million migrants given work permits $(750,000)$ were counted just twice, this means only 750,000 migrants were allowed to legalize, meaning only $12 \%$ of migrants were legally working!

FMS spokesman Konstantin Poltaranin asserted in 2009 that Moscow's municipal service sector, along with construction and trade, would not function without migrant labour (Belenev 2009). In

\footnotetext{
${ }^{16}$ Portal Tsentral'nyi Administrativnyi Okrug gorod Moskvy, 2 March 2010, available at: http://cao.mos.ru/document/2010/03/02/d19440/, accessed 14 March 2010.

${ }^{17}$ Federal Law \#115, O pravovom polozhenii inostrannykh grazhdan v Rossiyskoy Federatsii.

${ }^{18}$ Interview with Zhanna Zayonchkovskaya, 'Kvoty s potolka' in Ogoniok 20 August 2007.
} 
2008, Moscow employed 370,000 migrants in construction and trade alone. The quota for Moscow in 2008 was 300,000, which was exhausted by May. An additional 50,000 work permits were allotted July 1, which were again exhausted, this time within two weeks (Shpigal 2008). Quotas were increased in October, though there were not regional specifications attached to the increases. ${ }^{19}$ For 2009 the Moscow quota was 250,000 despite requests by employers for over 1 million foreign workers. For 2010, employers requested over 600,000 workers, yet the quota was further reduced to $200,000 .^{20}$

It is common knowledge in Moscow that many of these migrants live in government owned buildings. From a housing bloc on Bryusov pereulok only three blocks from the Kremlin (a property that lists as over $\$ 10,000$ per square meter), to the building of Government-owned media service Itar-Tass on Tverskoi Bulvar to the buildings surrounding Patriarchy Ponds, migrants of Central Asian appearance live and spend their free time. ${ }^{21}$ Each district administration of Moscow employing migrants houses them in areas nearby their work, often in buildings that have been deemed uninhabitable by the government. Poltaranin describes the situation as one in which taxpayers are footing the bill for water and electricity services in abandoned buildings housing illegal migrants. ${ }^{22}$

This situation has implications for Luzhkov's ability to maintain public legitimacy. On the positive side, using the cheap labour of migrants frees up funds for public works projects that produce development and city pride. Furthermore, the pervasive presence of street cleaners, as one example of municipal worker, keeps the city litter free in the summer and swept of snow in the winter, contributing to beautification as well as public safety. On the other hand, migrants are a visible reality in Moscow and instead of creating constructive policies to change the labour market, Luzhkov consistently passed the issue back to the federal government by demanding lower and lower quotas. In this case, Luzhkov walked a precarious line between making the federal government look incompetent for not solving migrant issues (potentially creating a new tipping point requiring further manual control) and giving them the opportunity to intervene powerfully in response to public demands.

Further, Luzhkov was actively critical of the FMS, which has led to very public disagreements played out in the media. The FMS for its part deemed Luzhkov's continued calls for effective immigration regulation populist, and argued that his rhetoric justifies opaque dealings with migrants (Belenev 2009). When Luzhkov passed an initiative in 2009 requiring all migrants to sign a rental contract with their landlord as a stipulation for registration, the FMS cancelled the procedure saying regional FMS offices did not have the right to add additional requirements to the federal laws (Shirmanova 2009). This sort of visible disagreement between separate branches

\footnotetext{
${ }^{19}$ Government Decision \#737, 3 October 2008.

${ }^{20}$ RIA Novosti, 24 June 2010, available at: http://www.rian.ru/moscow/20100624/249912263.html, accessed 7

October 2010.

${ }^{21}$ The value of the building on Bryusov pereulok is listed at http://www.domoway.ru/map/h50110/

${ }^{22}$ Nezavisimaya Gazeta, 12 March 2010.
} 
of the vertical of power discredits the uniform legal and political space that the regime purports to advance.

The following examples of elites in the construction and retail trade, two of the largest employers of migrant workers, demonstrate an even more precarious balance between public legitimacy and the stability of patronage networks. The example of elites in these industries as a part of Luzhkov's patronage network illustrates how illegal migrant labour is a beneficial resource, yet it is one that allows corruption to proceed unhindered until a tipping point is reached.

\section{Construction: Elena Baturina}

Luzhkov's wife, Elena Baturina, is the richest woman in Russia and embodies the new rich that typifies the Russian oligarchy. She is the owner and president of Inteco, a large construction company based in Moscow, and is herself worth an estimated \$2.9 billion. ${ }^{23}$ While it should not be inferred that all wealthy politicians (or their family members) are necessarily corrupt because they possess personal wealth, it has been alleged that Luzhkov and Baturina consistently defied anti-corruption legislation that requires public officials to disclose their income and property holdings (Nemtsov 2009). Inteco, founded in 1991, has either directly or through its subsidiaries received a number of government contracts. It has been involved in building projects that cover one million square meters of Moscow and environs and now controls around $20 \%$ of the housing market in the city (Nemtsov 2009). A January 2010 poll from the Levada Centre reports that a majority of Muscovites (65\%) believe that Baturina's success has come only with the help of Luzhkov (Levada Center 2010).

One of the projects listed on the Inteco website is the City Palace, a building in Moscow City, which was a construction project initiated by the Moscow City government with the intention that it would be the new home to the mayor's office and city Duma (Medvedev 2004). ${ }^{24}$ The development of Moscow City was a pet project of Luzhkov and involved a host of public works development, including roads and utilities as well as a new subway line. This new branch of the blue line on the Moscow metro consistently runs the newest trains, whereas many other lines only use older trains. The buildings of Moscow City loom in the skyline. A closer look, however, reveals temporary housing for migrant labourers who are involved in the construction projects. Housing containers are stacked three-high and stretch for blocks along the river. An expat working in Moscow City described her daily routine of arriving very early in the morning to work and passing through a sea of Central Asian workers to get to her building. An unemployed native Muscovite told me in unflattering terms how she would see Tajiks lounging outside the housing containers across from Moscow City in the afternoon hours. Though there were plans to

\footnotetext{
23 'The World's Billionaires: \#342 Elena Baturina', 10 March 2010, available at: http://www.forbes.com/lists/2010/10/billionaires-2010_Elena-Baturina_GXNS.html, accessed 19 March 2010. 24 "City Palace" multifunctional complex', available at: http://zaointeco.ru/index.php?p=22\&l=en, accessed 22 February 2010.
} 
dismantle these dwellings by May 2010 in order to improve the appearance of the area, a number of them remain. ${ }^{25}$

The construction industry in Russia is the largest sector of employment for migrant workers, employing $40 \%$ of all labour migrants (Tyuryukanova 2008). Of the five million construction workers in Russia, 13\% (as many as 19\% in Moscow) are migrant workers (ILO 2009;

Tyuryukanova 2008).. ${ }^{26}$ Experts estimate that if illegal immigrants are included in these calculations, migrants comprise at least $50 \%$ of all construction workers. If, according to these numbers, there are 2.5 million migrants in the construction industry, yet this number is only $40 \%$ of the total migrant population, a quota of less than 6.25 million will inevitably lead to illegality.

Current quotas are providing ample illegal labour to contribute to Baturina's fortunes. Illegal labour decreases construction costs and allows Inteco to maximize profitability. Some of Inteco's projects, including a number of buildings for Moscow State University, can be seen as public goods in the sense that they further the development of Moscow as a global city, contributing to the legitimacy of both the municipal and federal regimes. Furthermore, according to the Inteco website, Baturina sits on several high level committees dealing with the issue of affordable housing, positioning her to assist in providing concrete benefits to the public that would most certainly shore up the reputations of both municipal and federal leaders. Nevertheless, a brief glance at the residential facilities Inteco lists on their website reveals highimpact luxury facilities, calling into question the depth of Baturina's commitment to affordable housing. Furthermore allegations that Baturina benefits from her husband's political position became the subject of intense focus and could have contributed to Luzhkov's sacking in September 2010.

\section{Retail: Tel'man Ismailov}

Aside from ties to Baturina and the construction industry, Luzhkov had ties to business elites that are powerful in other sectors that traditionally employ migrants. The 2009 scandal over the closing of Cherkizovskii market has brought one of these relationships to light. Cherkizovskii market, the largest open air market in Eastern Europe, was owned by Tel'man Ismailov until it was closed on account of unsanitary conditions and in connection with contraband goods. In 2009 , Ismailov was ranked the $61^{\text {st }}$ richest man in Russia with a net worth of $\$ 600$ million. ${ }^{27}$ The

25 'Iz "Moskva Siti" ubiraut bytovki stroitelei', 21 January 2010, available at:

http://www.citynext.ru/newsfull.asp?id=277, accessed 23 February 2010.

${ }^{26}$ It is immediately clear that these data are derived from official sources. $13 \%$ of 5 million is 650,000 migrants employed in the construction sector. If 650,000 migrants are $40 \%$, the total migrant population would be 1.6 million migrants, which is substantially lower than the estimated 6-7 million total migrants currently in Russia (acc to Tyuryukanova 2009).

27 ‘100 bogateishikh biznesmenov Rossii 2009: Tel’man Ismailov’, available at: http://www.forbesrussia.ru/rating/100-bogateishih-biznesmenov-rossii/2009/ismailov, accessed 19 March 2010. 
events surrounding the closing of the market are relevant to this discussion on two levels. First, Cherkizovskii market was manned almost entirely by migrant labour and therefore offers a direct example of one portion of the migrant labour market. Second, Cherkizovskii quickly became an issue of political intrigue at the upper-most echelons and offers a further example of manual control by Prime Minister Putin.

As of 2007, there has been a ban on foreign workers in retail markets and in the sale of alcohol and pharmacy products. ${ }^{28}$ The ban came about as result of the quota mechanism, essentially setting the quota for workers in these enterprises to zero. It was instituted as a populist response to public complaints about the presence of migrants in the markets in the run-up to 2007 elections and as a security response to increasing criminality (i.e. violation of labour rights and sanitary norms) and contraband goods (Vitkovskaya 2009; Mikhaelova \& Tyuryukanova 2009). ${ }^{29}$ The legislation was not effective, evidenced by the estimated $\$ 2$ billion worth of contraband goods were recovered from the premises of Cherkizovskii market after its closing, showing persisting criminality after the 2007 ban (Antonova 2009). Neither was the ban effective at eliminating the presence of migrants in retail markets, as Cherkizovskii was manned primarily by migrants from the CIS, China and Vietnam. In the weeks following the market closing 900 migrants were found to be without documents(Moshkin 2009), which is to say nothing of those with counterfeit documents or documents procured by paying bribes to corrupt bureaucrat.

Cherkizovskii was continually under threat of being closed by the city government from 2006 on the premise of ending underground trading processes Grekova 2006; Kalinovskii \& Vladimirova 2008). The closing was continually delayed, however, as Luzhkov used his role atop the municipal patronage networks to allow the market to remain open and continue to amass profits for Ismailov. As late as April 2009 Luzhkov announced the market would not be closed until 2010 (Zubrin 2008). ${ }^{30}$ In 2008, federal agencies became directly involved when the Federal Security Service (Federal'naya sluzhba bezopasnosti, FSB) took up a case that investigated police involvement in smuggling of counterfeit goods to markets throughout Russia including Cherkizovskii (Kanev 2008). In June 2009, days after Ismailov threw a lavish grand opening at his new $\$ 1$ billion hotel in Turkey (a party whose guest list included a number of Hollywood stars as well as Luzhkov and Baturina), Putin spoke sharply against illegal imports as a threat to

\footnotetext{
${ }^{28}$ Though the ban was instituted effective April 1, 2007, the category of wholesale and retail trade remains a part of the calculation of FMS and GKS statistics and is growing. The category of wholesale and retail trade as a sphere of employment is combined with auto and general household repair services. According to Goskomstat data, in 2006 270,944 migrants were employed in this sphere, in 2007: 330,000 and in 2008: 411,800.

${ }^{29}$ Thus migration policy in this case was formulated in order to justify a "clean sweep" of markets, which had become a haven for counterfeit drugs, alcohol and other goods and for other criminal practices (Vitkovskaya 2009).

30 ‘Cherkizovskiii poka ne zakryvaut', Vechernyaya Moskva, 15 April 2009.
} 
the federal budget and vowed a crackdown, exercising manual control over the situation. ${ }^{31}$ Federal agencies closed the market later that month, bypassing any city jurisdiction. Many suspect that the federal government was angered at the fact that Ismailov was spending the fortune he earned in Russia abroad (Franchetti 2009).

Shortly after the market was closed on June 29, 2009 Ismailov's brother Faisal Izmailov resigned his position as the acting prefect of the northern administrative district (severnyi administrativnyi okrug) of Moscow (Perekrest 2009). The position was offered to Oleg Mitvol, who had previously been the Deputy Head of Rosprirodnadzora, the Federal environmental service that was instrumental in ensuring Cherkizovskii remained closed. Mitvol was appointed by Luzhkov, but had a reputation for being an anti-corruption bull dog in the service of the Kremlin. ${ }^{32}$ At the time many believed the closing of Cherkizovskii was a signal to Luzhkov from the Kremlin that his influence and ability to protect the interests of those around him was waning. It is an excellent example of manual control because it shows the Kremlin's efforts to balance the benefits the federal powers receive from Luzhkov and his patronage network (economic prosperity, stability and votes in national elections) with efforts to maintain a public image of being tough on oligarchs and corruption. In this case manual control was necessary because a tipping point had been reached when Ismailov was far too cavalier about his ill-gotten wealth. Television coverage of the opening of the Turkish hotel juxtaposed scenes of lavish wealth against those of the deplorable living conditions of migrants in Cherkizovskii. Of the Muscovites I spoke with at the time, however, more were appalled by Ismailov's behaviour than the mistreatment of migrants.

Putin was able to immediately mobilize agencies to close Cherkizovskii market, showing once again that he would act decisively against the corruption that mobilizes public disgust. The cycle of manual control is interesting in this case. Manual control, as the hypothesis of this article indicates, provides a large pool of cheap illegal labour to political and economic elites through low quotas. The government manipulates the quota system to provide direct benefits to economic actors while maintaining an aura of restriction to satisfy the public. But by allowing corruption to proceed, a tipping point is almost certain to occur once popular legitimacy can no longer be balanced with keeping patronage networks intact. At this point, elites who have not maintained vigilant loyalty are at risk of being the victim of a further round of manual control.

\section{Conclusion}

This article has focused on the Moscow case, showing how elites negotiate and control the migration situation. The dynamics of manual control depend in large part on the patron-client relationships between federal and regional elites and therefore it is important to consider how

31 'V.V. Putin provel zasedanie Presidiuma Pravitelstva Rossiiskoi Federatsii’ 1 June 2009,

http://www.government.ru/content/governmentactivity/mainnews/archive/2009/06/01/3056300.htm, accessed 22

March 2010.

32 RIA Novosti, 29 June 2009, available at: http://www.rian.ru/politics/20090629/175803628.html, accessed 12

March 2010. 
these findings can be generalized for the whole of Russia. Because quotas are set separately for each region and because labour market and social acceptance of migrants vary across regions (Voronina 2006; Gavrilova 2001), regional elites must negotiate with federal elites to set desirable quotas. In Sverdlovsk, a region that has increasingly worked to attract migrants (Ruble forthcoming), quotas have decreased dramatically from 133,000 in 2009 to 67,000 in 2010 to 43,000 in 2011, following national trends. Yet while quotas on the whole have decreased consistently since they were instituted, regional figures do not uniformly show the same trend. Take Krasnodar for example, where there has been much wrangling over quota numbers including calls from the governor to reduce quotas in the face of the 2008 financial crisis in order to protect the labour market for natives. ${ }^{33}$ Quotas have fluctuated wildly (28,000 in 2008, 48, 000 in 2009, 25,000 in 2010 and 43,000 in 2011) despite continued need for migrant workers to man construction projects ahead of the 2014 Sochi Olympics and estimates that there are hundreds of thousands of illegal migrants in the region. ${ }^{34}$ Thus despite fluctuating numbers, Krasnodar follows the trend of keeping a substantial portion of the migrant population in the informal realm. Nevertheless more work must be done in the future to assess the regional patterns of negotiating and instituting migrant quotas.

Migration is a key policy issue because it is represents the convergence of pressing demographic, social and elite interests. Control over migration is essential to the direction of the entire labour market and is thus significant to the long-term economic health of Russia. The scale of demographic crisis, xenophobia in the populous and the degree of entrenched patronage ties linking political and economic actors converges with increasing authoritarianism and has led to the situation in which manual control is necessary to manage varying interests. The nature of manual control is flexible and allows the Kremlin to manage disparate demands immediately and personally. Nevertheless, it is a tactic that focuses on short term solutions to deeply complex problems.

Diverting immigrants to the shadow sector through low quotas provides cheap labour to satisfy economic actors while maintaining a guise of strict formal order to satisfy xenophobic tendencies in society. Legitimacy for the regime is shored up on the mass level and elites are managed through reasserting patronage ties. The patronage resource of migrant labour is then distributed to economic actors from the elite level to owners of small enterprises. In return, economic actors provide a number of benefits to the Kremlin including votes for the party of power, political loyalty and a stable system of informality that continues to absorb migrant labour into the shadow economy. All the while, the larger issue of migrants as a potential solution to the demographic crisis is left unaddressed and no progress is made on solving long term gaps in the labour market.

\footnotetext{
33 'V Krasnodarskom krae, sokratil kvotu dlya trudovykh migrantov', Rossiya 1 Kuban, 12 December 2008, available at: http://krasnodar.rfn.ru/rnews.html?id=12993, accessed 2 May 2011.

34 ‘Kuban’ v 2011 godu ne uvelichit kvoty dlyz trudovykh migrantov', BiznesN’yus.ru, 24 January 2011, available at: http://www.biznesnews.ru/region/2011/01/kuban-v-2011-godu-ne-uvelichit-kvoty-dlya-trudovykh-migrantov/,
} accessed 2 May 2011. 
Opposition leader and constant critic of Putin's regime Boris Nemtsov believes the use of manual control is a display of weakness. In response to the installation of video cameras to supervise the reconstruction of houses discussed earlier, Nemtsov says "When Putin sticks web cameras in the Vyksa district to check if building materials are being stolen, he is admitting his own impotence... This is manual control, and you can't run a country this big by hand" (Arkhipov \& Pronina 2010). Nemtsov alludes to a very important component of governance: trust. If Putin cannot trust those around him to implement his wishes, he will find himself at the top of an unmaneuverable political machine. Insofar as manual control is a mechanism that clarifies how the patronage system should act, it is useful and will continue to be an effective means of governance. But manual control cannot exist apart from a system of implementation, or a loyal cadre of elites whose translation of decrees into practice make their content meaningful.

The primary problem with manual control, as opposed to predictable, regularized legal and bureaucratic channels is that it is a potentially fragile tool that sets up the possibility for power struggles between key elites. As elites struggle over the distribution of resources, the concentration of authoritative decision-making into the hands of just one or a few individuals insures that challenging the patronage system will carry enormous costs. Though the true reasons for Luzhkov's firing are wildly speculative, what is certain is that he fell out of favour with his patrons and paid a direct and costly price. Luzhkov joins the ranks of a number of former political and economic elites that have been stripped of their jobs or livelihoods as a result of confrontation with the Kremlin.

For the time being, power is becoming more and more institutionalized in the office of the prime minister and key policy decisions are being issued from the government rather than from the president. Does the fact that Luzhkov was fired by Medevdev's presidential decree unravel the argument that power is concentrated in the hands of Putin? Essentially not. In fact, it is necessary that Luzhkov was removed according to the law in order for the regime to maintain its guise of constitutionality. Furthermore, the institution of the presidency cannot be totally emasculated (i.e. by shifting the power to appoint and dismiss regional executives) if Putin wants to return to the office. Most importantly, Medvedev's action insulates Putin from any potential political fallout. The appointment of Putin's chief of staff Sergei Sobyanin to the mayoral post indicates that it is Putin's patronage networks continue to be of the utmost importance in the governance of Moscow. Will this type of continual transfer of institutional power from president to prime minister lead to problems in the future if Putin is to return to the office of president? Likely not, as any transfers that have been afforded the prime minister's office can be easily returned to the purview of the president so long as the patronage system remains intact.

Despite Luzhkov's removal, the patronage network cannot be entirely dismantled as it would be too destabilizing for the entire political and economic system. It is more efficient and expedient to keep the majority of the network intact but remove a few key figures in order to test the loyalty of elites and remind them of the power of manual control. On the whole, the removal of Luzhkov does not reflect an anti-corruption move, evidenced by the fact that quotas for migrant work permits in 2011 have been decreased yet again to 160,000 in Moscow. Thus the patronage resources continue to flow from the federal government to municipal elites as a reward for their ongoing loyalty. 


\section{Works Cited}

Alexseev, M. (2010) ' Majority and Minority Xenophobia in Russia: The Importance of Being Titulars', Post-Soviet Affairs, 26, 2, April-June.

Andrienko, Y. \& Guriev, S. (2005) Understanding Migration in Russia, CEFIR Policy Paper 23 (Moscow, New Economic School), available at:

http://www.cefir.ru/download.php?id=216,accessed 13 May 2010).

Antonova, M. (2009) '100 Detained Around Cherkizovsky Market', Moscow Times, 6 July.

Arkhipov, I. \& Pronina, L. (2010) 'Putin Fire Webcams Show Power Pyramid Weakens Regions', Bloomberg Businessweek, 25 August, available at http://www.businessweek.com/news/2010-08-25/putin-fire-webcams-show-power-pyramidweakens-regions.html, accessed 4 September 2010.

Becker, J. (2004) 'Lessons from Russia: A Neo-Authoritarian Media System', European Journal of Communication 19, 2, June.

Belenev, G. (2009) 'Moskva otdana migrantam', Nezavisimaya Gazeta, 18 December.

Bratersky, A. (2010) 'New Work Permits to Be Offered To Migrants' The Moscow Times, 12 January.

Colton, T. (1999) 'Understanding Iurii Luzhkov', Problems of Post-Communism, 48, 5, September/October.

277-303.

Dmitriyev, S. (2007) 'Migration Aggravation', Moscow News, 19 January.

Egorova, E. (2009) 'Deyatel'nost' Federal'noy migratsionnoy sluzhby Rossii po formirovaniyu i razvitiyu novoy migratsionnoy politiki' in Vitkovskaya, G., Platonova, A. \& Shkolnikov, V. (eds) (2009) Novoe Migratsionnoe Zakonodatelstvo Rossiiskoi Federatsii: Pravoprimenitelnaya Praktika (Moscow, International Organization for Migration, Federal Migration Service of Russia, Organization for Security and Cooperation in Europe).

FMS (2008a) Kvoty na vydachy razreshenii na rabotu $v 2008$ ischerpany na 50 protsentov (Moscow, Federal Migration Service), available at:

http://www.fms.gov.ru/press/news/news_detail.php?ID=19168/, accessed December 14, 2009.

FMS (2008b) Regiony v avgust poluchat dopolnitelnuyu kvotu na trudovykh migrantov (Moscow, Federal Migration Service), available at:

http://www.fms.gov.ru/press/news/news_detail.php?ID=22653/, accessed December 14, 2009.

FMS (2010) Statisticheskie dannye po forme 1-RD "Rezul'taty deyatel'nosti territorial'nykh organov za 12 mesyatsev 2009 goda (Moscow, Federal Migration Service), available at: http://www.fms.gov.ru/about/ofstat/stat_1_rd/part_6.php, accessed 30 April 2010. 
Franchetti, M. (2009) 'Vladimir Putin 'furious' over flaunting oligarch Tel'man Ismailov' Times Online, 28 June, available at:

http://www.timesonline.co.uk/tol/news/world/europe/article6591398.ece, accessed 15 March 2010.

Gavrilova, I. (2001) 'Migration Policy in Modern Russia: To Be or Not to Be', Perspectives on European Politics and Society, 2, 2, May.

Goldman, M. (2005) 'Political Graft: The Russian Way', Current History, 104, 684, October.

Goskomstat (2009) Chislennost' inostrannykh rabotnikov, osushchestvleyavshikh trudovuyu deyatel'nost' v Rossii (Moscow, Federal'naya Sluzhba Gosudarstvennoi Statistiki), available at: http://www.gks.ru/bgd/regl/b09_13/IssWWW.exe/Stg/html1/05-14.htm, accessed 30 April 2010.

Grekova, O. (2006) 'Rynok. Cherkizovskiii dobazarilcya', Moskovskii Komsomolets, 31 August.

Gritsyuk, M. (2010) 'Nelegalka Fregen Bok', Rossisskaya Gazeta, 28 January.

Gritsyuk, M. (2008) 'Inostrantsev urezali: Kvota na migrantov snizhena vdvoe', Rossiskaya Gazeta, 12 December.

Hahn, G. (2001) 'Putin's "Federal Revolution": The Administrative and Judicial Reform of Russian Federalism', East European Constitutional Review, 10, 1, Winter.

Haspel, M., Remington, T. \& Smith, S. (2006) 'Lawmaking and Decree Making in the Russian Federation: Time, Space, and Rules in Russian National Policymaking', Post-Soviet Affairs 22, 3, July-September,.

Hendley, K. (2009) 'Telephone Law' and the 'Rule of Law': The Russian Case', Hague Journal on the Rule of Law, 1, 2, September.

Hyde, M. (2001) 'Putin's Federal Reforms and Their Implications for Presidential Power in Russia', Europe-Asia Studies 53, 5, July.

ILO(2009) Preventing Forced Labour Exploitation and Promoting Good Labour Practices in the Russian Construction Industry (Geneva, International Labour Organization and European Bank for Reconstruction and Development).

Ioffe, G. \& Zayonchkovskaya, Z. (2010) Immigration to Russia: Why It Is inevitable, and How Large It May Have to Be to Provide the Workforce Russia Needs, NCEEER Working Paper (Seattle, The National Council for Eurasian and East European Research).

Ivakhnyuk, I. (2009) The Impact of the Economic Crisis on Migration Trends and Migration Policy in the Russian Federation and the Eastern European and Central Asian Area, Analytical Report (Moscow, International Organization for Migration).

Jahn, A., \& Straubhaar, T. (1999) 'A Survey of the Economics of Illegal Migration', in BaldwinEdwards, M. \& Arango, J. (eds) (1999) Immigrants and the Informal Economy in Southern Europe (Portland, OR, Frank Cass Publishers). 
Kalinovskii, I. \& Vladimirova, E. (2008) 'Konchai bazar!' Rossiiskaya Gazeta, 3 April.

Kanev, S. (2008) 'Taina Cherkizovskogo rynka', Novaya Gazeta, 2 June.

Konitzer, A. \& Wegren, S (2006) 'Federalism and Political Recentralization in the Russian Federation: United Russia As the Party of Power', Publius: The Journal of Federalism, 36, 4.

Korobkov, A\& Zaionchkovskaia, Z. (2004) 'The changes in the migration patterns in the postSoviet states: the first decade', Communist and Post-Communist Studies, 37, 4, December.

Kroschenko, M. \& Zibarev, D. (2009) 'Review of current approaches in monitoring and assessing labour shortages in the Russian Federation and methods/procedures in migration planning', in Baruah, N. (ed.) (2009) Review of Approaches in Measuring the Need for Migrant Workers and Labour Migration Planning Russian Federation and International Experience (Moscow, International Labor Organization).

Ledeneva, A. (2008) 'Telephone Justice in Russia', Post-Soviet Affairs, 24, 4, October-December.

Levada Center (2010) Moskvichi o korrumpirovannosti Yurii Luzhkov, 31 January, (Moscow, Levada Center), available at: http://www.levada.ru/press/2010020103.html, accessed 15 March 2010.

Lipman, M. (2005) 'Constrained or Irrelevant: The Media in Putin's Russia', Current History, 104, 684, October.

Luzhkov, Y. (2006) 'Migratsiya Zdravogo Cmysla', Rossiskaya Gazeta, 10 November.

Medvedev, R. (2004) 'The Yurii Luzhkov Phenomenon', Russian Politics and Law, 42, 5, September/October.

Mikhaelova, E. \& Tyuryukanova, E. (2009) 'Migranti v roznichnoi torgovle: effekt zapretov', in Vitkovskaya, G., Platonova, A. \& Shkolnikov, V. (eds) (2009) Novoe Migratsionnoe Zakonodatelstvo Rossiiskoi Federatsii: Pravoprimenitelnaya Praktika (Moscow, International Organization for Migration, Federal Migration Service of Russia, Organization for Security and Cooperation in Europe).

Moshkin, M. (2009) 'Dogovor o nerasprostranenii', Vremya Novosti, 15 July.

Nemtsov, B. (2009) Luzhkov. Itogi (Moscow, Solidarnost') available at: http://www.nemtsov.ru/?id=705917\&PHPSESSID=39f1e74a3faa7ecf8a54fbf772c94c40 (accessed March 13, 2010).

Orttung, R. (2006) Causes and Consequences of Corruption in Putin's Russia, PONARS Policy Memo 430 (Washington DC, PONARS Eurasia)available at: http://csis.org/publication/ponarspolicy-memo-no-430-causes-and-consequences-corruption-putins-russia, accessed 2 May 2011.

Panfilov, O. (2000) 'Putin and the Media--No Love Lost', East European Constitutional Review, $9,1 / 2$, Winter/Spring.

Perekrest, V. (2009) 'Cherkizovo: brat za brata', Izvestiya, 16 June. 
Petrov, N., Lipman, M. \& Hale, H. (2010) Overmanaged Democracy in Russia: Governance Implications of Hybrid Regimes, Carnegie Papers 106 (Washington DC, Carnegie Endowment for International Peace).

Pomeranz, W. (2009) 'President Medvedev and the Contested Constitutional Underpinnings of Russia's Power Vertical', Demokratizatsiya, 17, 2, Spring.

Remington, T. (2006) 'Presidential Support in the Russian State Duma', Legislative Studies Quarterly, 31, February.

Reuter, O.J. \& Remington, T. (2009) 'Dominant Party Regimes and the Commitment Problem: The Case of United Russia', Comparative Political Studies, 42, 4, April.

Ross, C. (2005) 'Federalism and Electoral Authoritarianism Under Putin', Demokratizatsiya, 13, 3 , Summer.

Ruble, B. (forthcoming) 'Adding Human Diversity to Urban Political Economy Analysis: The Case of Russia', in Good, K., Triadafilopoulos, P. \& Turgeon, L (eds.) (1996) Segmented Cities? How Urban Contexts Shape Ethnic and Nationalist Politics (Vancouver, University of British Columbia Press)

Sakwa, R. (2010) 'The Dual State in Russia', Post-Soviet Affairs, 26, 3, July-September.

Schenk, C. (2010) 'Open Borders, Closed Minds. Russia's Changing Migration Policies: Liberalization or Xenophobia?', Demokratizatsiya, 18, 2, Spring.

Shirmanova, T. (2009) 'Zhivite, gde khotite', Trud, 4 February.

Shpigal, M. (2008) 'Inostrantsev opyat ne puskayut', Vedomosti, 15 July.

Slider, D. (2008) 'Putin's “Southern Strategy”: Dmitriy Kozak and the Dilemmas of Recentralization', Post-Soviet Affairs, 24, 2, April-June.

Taylor, B. (2007) Russia's Power Ministries: Coercion and Commerce (Syracuse University, Institute for National Security and Counterterrorism)

Tyuryukanova, E. (2008) 'Labour migration from CIS to Russia: New Challenges and Hard Solutions', Presentation at Empires \& Nations, Paris, 3-5 July 2008.

Tyuryukanova, E. (2009) 'Monitoring Migratsionnoi Politiki: Itogi 2007 i 2008 godov', Presentation at Nauchni Sovet FMS, Moscow Center of Migration Research, Russian Academy of Sciences, 10 April 2009.

Vitkovskaya, G. (2009) 'Novoe migratsionnoe zakonodatelstvo Rossii: liberalizatsiya v tselyakh legalizatsii', in Vitkovskaya, G., Platonova, A. \& Shkolnikov, V. (eds) (2009) Novoe

Migratsionnoe Zakonodatelstvo Rossiiskoi Federatsii: Pravoprimenitelnaya Praktika (Moscow, 
International Organization for Migration, Federal Migration Service of Russia, Organization for Security and Cooperation in Europe).

Voronina, N. (2006) 'Outlook on Migration Policy Reform in Russia: Contemporary Challenges and Political Paradoxes', in Rodriguez Rios, R. (ed.) (2006) Migration Perspectives: Eastern Europe and Central Asia (Vienna, International Organization for Migration).

Weber, M. (1978) Economy and Society (Berkeley, University of California Press).

White, S. \& McAllister, I. (2003) 'Putin and His Supporters', Europe-Asia Studies, 55, 3, May.

Whitmore, B. (2010) 'The Luzhkov Phenomenon', RFE/RL, 12 May, available at: http://www.rferl.org/content/The_Luzhkov_Paradox/2040348.html, accessed 14 July 2010.

Wilson, K. (2006) 'Party-System Development Under Putin' Post-Soviet Affairs, 22, 4, OctoberDecember.

Zherebenkov, E. (2007) 'Ruchnoi Rezhim', Itogi, 22 October, available at:

http://www.itogi.ru/archive/2007/43/13476.html, accessed 18 September 2010.

Zubrin, S. (2008) 'Khronika ChP', Mosckovskaya Pravda, 29 July. 